\title{
Congenital Hydrocephalus
}

National Cancer Institute

\section{Source}

National Cancer Institute. Congenital Hydrocephalus. NCI Thesaurus. Code C98876.

Hydrocephalus that is present at birth. 